\title{
Pyrrolidine Dithiocarbamate Activates Akt and Improves Spatial Learning in APP/PS1 Mice without Affecting $\beta$-Amyloid Burden
}

\author{
Tarja M. Malm, ${ }^{1}$ Henna Iivonen, ${ }^{1}$ Gundars Goldsteins, ${ }^{1}$ Velta Keksa-Goldsteine, ${ }^{1}$ Toni Ahtoniemi, ${ }^{1}$ Katja Kanninen, ${ }^{1}$ \\ Antero Salminen, ${ }^{2,4}$ Seppo Auriola, ${ }^{3}$ Thomas Van Groen, ${ }^{2}$ Heikki Tanila, ${ }^{1,4}$ and Jari Koistinaho ${ }^{1,5}$ \\ ${ }^{1}$ A. I. Virtanen Institute for Molecular Sciences and Departments of ${ }^{2}$ Neuroscience and Neurology and ${ }^{3}$ Pharmaceutical Chemistry, University of Kuopio, \\ and Departments of ${ }^{4}$ Neurology and ${ }^{5}$ Oncology, Kuopio University Hospital, FIN-70211 Kuopio, Finland
}

Pyrrolidine dithiocarbamate (PDTC) is a clinically tolerated inhibitor of nuclear factor- $\kappa \mathrm{B}(\mathrm{NF}-\kappa \mathrm{B})$, antioxidant and antiinflammatory agent, which provides protection in brain ischemia models. In neonatal hypoxia-ischemia model, PDTC activates Akt and reduces activation of glycogen synthase kinase $3 \beta$ (GSK-3 $\beta$ ). Because chronic inflammation, oxidative stress, and increased GSK- $3 \beta$ activity are features of Alzheimer's disease (AD) pathology, we tested whether PDTC reduces brain pathology and improves cognitive function in a transgenic animal model of AD. A 7 month oral treatment with PDTC prevented the decline in cognition in AD mice without altering $\beta$-amyloid burden or gliosis. Moreover, marked oxidative stress and activation of NF- $\kappa$ B were not part of the brain pathology. Instead, the phosphorylated form of GSK-3 $\beta$ was decreased in the AD mouse brain, and PDTC treatment increased the phosphorylation of Akt and GSK-3 $\beta$. Also, PDTC treatment increased the copper concentration in the brain. In addition, PDTC rescued cultured hippocampal neurons from the toxicity of oligomeric $\mathrm{A} \beta$ and reduced tau phosphorylation in the hippocampus of $\mathrm{AD}$ mice. Finally, astrocytic glutamate transporter GLT-1, known to be regulated by Akt pathway, was decreased in the transgenic AD mice but upregulated back to the wild-type levels by PDTC treatment. Thus, PDTC may improve spatial learning in AD by interfering with Akt-GSK pathway both in neurons and astrocytes. Because PDTC is capable of transferring external $\mathrm{Cu}^{2+}$ into a cell, and, in turn, $\mathrm{Cu}^{2+}$ is able to activate Akt, we hypothesize that PDTC provides the beneficial effect in transgenic AD mice through $\mathrm{Cu}^{2+}$-activated Akt pathway.

Key words: Alzheimer's disease; inflammation; glycogen synthase; phosphorylation; $\beta$-amyloid; learning and memory

\section{Introduction}

There is compelling evidence that aggregation of amyloid- $\beta(\mathrm{A} \beta)$ peptides $A \beta_{1-42}$ and $A \beta_{1-40}$ is a key mediator of the pathogenesis of Alzheimer's disease (AD), a dementing neurodegenerative disease. $\mathrm{A} \beta$ peptides are directly neurotoxic by mechanisms involving oxidative stress, mitochondrial dysfunction, apoptosis, and hyperphosphorylation of tau, a microtubule-associated protein that becomes dysfunctional with hyperphosphorylation, causing thereby neurofibrillary tangle formation and abnormal neuronal functions (Behl et al., 1994; Goodman and Mattson, 1994; Busciglio et al., 1995; Meda et al., 1995; Anderson et al., 1996; London et al., 1996; Estus et al., 1997). A $\beta$ also disturbs normal synaptic functions (Davies and Maloney, 1976; Beach et al., 2000) and increases brain susceptibility to injury (Nakagawa et al., 1999, 2000; Lauderback et al., 2001; Koistinaho et al., 2002). In addition

Received Aug. 29, 2006; accepted Feb. 18, 2007

This work was supported by the Sigrid Juselius Foundation, Academy of Finland, and the Nordic Centre of Excellence Program in Molecular Medicine 2004-2009 entitled "Neurodegeneration." We thank Dr. David Borchelt (University of South Florida, Gainesville, FL) and Dr. J. Jankowsky (California Institute of Technology, Pasadena, CA) for providing the breeder mice for the study.

Correspondence should be addressed to Dr. Jari Koistinaho, A. I. Virtanen Institute for Molecular Sciences, University of Kuopio, P.0. Box 1627, FIN-70211 Kuopio, Finland. E-mail: jari.koistinaho@uku.fi.

DOI:10.1523/JNEUROSCI.0059-07.2007

Copyright $\odot 2007$ Society for Neuroscience $\quad$ 0270-6474/07/273712-10\$15.00/0 to its direct harmful effect on neurons, aggregated $\mathrm{A} \beta$ activates microglia and astrocytes (Akiyama et al., 2000) to secrete proinflammatory molecules, reactive oxygen species, and other neurotoxins, causing indirect neurotoxicity. Moreover, expression of glutamate transporter 1 (GLT-1), an astrocytic glutamate transporter maintaining glutamate at nontoxic concentrations, is decreased in the $\mathrm{AD}$ brain and in $\mathrm{A} \beta$-treated astrocytes (Harris et al., 1996; Masliah et al., 1996, 2000; Liang et al., 2002). There are several hypotheses for the molecular mechanisms for these pathogenic cascades triggered by $\mathrm{A} \beta$ in neurons and glia, including the pathway mediated by glycogen synthase kinase $3 \beta$ (GSK$3 \beta$ ) (Grimes and Jope, 2001). GSK-3 $\beta$ can be dephosphorylated and activated by $\mathrm{A} \beta$ in vitro, and its levels are increased in $\mathrm{AD}$ brain (Takashima et al., 1996; Pei et al., 1997, 1999; Hye et al., 2005). Activation of GSK-3 $\beta$ can lead to apoptotic neuronal death, contribute to hyperphoshorylation of tau, and result in energy depletion with stress conditions. GSK-3 $\beta$ may also inhibit the expression of transcription factors that support cell survival (Grimes and Jope, 2001).

Dithiocarbamates are metal chelating compounds reported to be potent antioxidants and inhibitors of nuclear factor- $\kappa \mathrm{B}$ (NF$\kappa \mathrm{B})$, a transcription factor regulating expression of proinflammatory and proapoptotic genes (Schreck et al., 1992; Liu et al., 1999; Hayakawa et al., 2003). Dithiocarbamates have previously been 
used in the treatment of metal poisoning and fungal infections in humans, and their derivatives have been considered for use in treatment of patients with AIDS (Reisinger et al., 1990). Pyrrolidine dithiocarbamate (PDTC) is also protective in animal models of stroke, neonatal asphyxia, and spinal cord trauma (La Rosa et al., 2004; Nurmi et al., 2004, 2006) possibly because of its antiinflammatory or antioxidant properties. However, PDTC treatment activates Akt, inhibits GSK-3 $\beta$, and reduces apoptosis in a neonatal asphyxia model (Nurmi et al., 2006).

Here, we report that oral PDTC treatment improves spatial learning of APP/PS1 transgenic mice without altering A $\beta$ burden or glial activation. Whereas the brain pathology of APP/PS1 mice does not involve detectable increase in NF- $\kappa \mathrm{B}$ activation or marked oxidative stress, we found that the active form of GSK-3 $\beta$ is increased in APP/PS1 transgenic mice and that PDTC activates Akt and downregulates the GSK-3 $\beta$ pathway.

\section{Materials and Methods}

Animals. The APdE9 transgenic mice used in this study were generated by coinjection of chimeric mouse/human APP695 harboring the Swedish mutation and human PS1-dE9 vectors, both controlled by their own mouse prion protein promoter element (Jankowsky et al., 2004). The double transgenic mice were backcrossed to C57BL/6J strain for six generations to create APdE9 transgenic (APP/PS1, tg) mice in C57BL/6J background. Wild-type (wt) siblings were used as controls.

PDTC treatment. Tg and their wt controls $(n=20)$ were treated with PDTC $(20 \mathrm{mg} / \mathrm{kg}$ per day) in drinking water for 7 months, starting at the age of 9 months. The individual water consumption of the mice was assessed before starting the drug treatment and assumed to be constant throughout the experiment. The control groups received normal drinking water. No differences in body weights between PDTC- and $\mathrm{H}_{2} \mathrm{O}$ treated mice were recorded. The mice were killed at the age of 16 months. In addition, separate groups of tg mice $(n=4-6)$ were given PDTC or normal drinking water for 4 months and analyzed by immunohistochemistry at the age of 9.5 months.

Morris water maze. The effect of PDTC treatment on spatial learning and memory was assessed by Morris water maze at the age of 16 months. A black plastic pool with a diameter of $120 \mathrm{~cm}$ was used containing a submerged escape platform (black square; $14 \times 14 \mathrm{~cm}$ ) $1.0 \mathrm{~cm}$ below the water surface. The temperature of the water was kept constant throughout the experiment $\left(20 \pm 0.5^{\circ} \mathrm{C}\right)$, and a 10 min recovery period was allowed between the training trials.

The mice were first trained for $2 \mathrm{~d}$ to find the submerged platform with the help of an alley $(1 \mathrm{~m} \times 14 \mathrm{~cm} \times 25 \mathrm{~cm})$ leading to the platform. The task acquisition consisted of 4 consecutive days of testing, with five trials per day. If the mouse failed to find the escape platform within the maximum time $(60 \mathrm{~s})$, the animal was placed on the platform for $10 \mathrm{~s}$ by the experimenter. The platform location was kept constant, and the starting position varied between four constant locations at the pool rim. Mice were placed in the water with their nose pointing toward the wall at one of the starting points in a random manner. On the last trial of the fifth day, the platform was removed, and the mice were allowed to swim for $60 \mathrm{~s}$ to determine their search bias. Timing of the latency to find the submerged platform was started and ended by the experimenter. A computer connected to an image analyzer (HVS Image, Hampton, UK) monitored the swim path. Swimming speed was measured by dividing the path length by the time to find the platform. Only mice with a swimming speed $>8 \mathrm{~cm} / \mathrm{s}$ in all trials were included in the analysis to discard occasional floating mice. Search bias during the probe trial was measured by calculating the time the mice spent in the platform quadrant. The behavioral data were analyzed by using repeated-measures ANOVA (ANO$\mathrm{VA}_{\mathrm{rm}}$ ), and differences were accepted as significant at $p<0.05$.

Electrophoretic mobility shift assay. Electrophoretic mobility shift assay (EMSA) was performed as described previously in detail (Helenius et al., 1996). Nuclear proteins were isolated from fresh frozen cortical samples according to a modified protocol of Dignam et al. (1983). Doublestranded consensus and mutated oligonucleotides for NF- $\kappa$ B and activa- tor protein 1 (AP-1) binding sites were from Santa Cruz Biotechnology (Santa Cruz, CA). Probes were labeled with T4 polynucleotide kinase (Promega, Madison, WI) and unspecific binding was blocked by $2 \mu \mathrm{g}$ of poly(dI-dC):polyI(dI-dC) (Roche Applied Science, Basel, Switzerland) in an assay volume of $20 \mu \mathrm{l}$. The binding assays were performed as described previously (Helenius et al., 1996). In supershift assays, the specific antibodies (Santa Cruz Biotechnology) to p50 (sc-1192X), p65 (sc-372X), and YY1 (sc-281X) were added for $1 \mathrm{~h}$ after the binding reaction. Bound and free probes were separated in a native $4 \%$ polyacrylamide gel, and radioactive bands were visualized with STORM $860 \mathrm{im}-$ ager (GE Healthcare, Little Chalfont, Buckinghamshire, UK). Pixel volumes of specific bands were calculated with ImageQuaNT software (GE Healthcare). The EMSA data were analyzed by using ANOVA in SPSS software and statistical significance was assumed if $p<0.05 . N=$ $8-10$ per group.

Immunohistochemistry. The pentobarbital-anesthetized mice were transcardially perfused with heparinized saline. The brains were dissected out and the left hemisphere was further dissected into hippocampal and cortical samples and snap frozen in liquid nitrogen. The right hemisphere was immersion-fixed with $4 \%$ paraformaldehyde for $21 \mathrm{~h}$ and cryoprotected in 30\% sucrose in phosphate buffer for $48 \mathrm{~h}$. The hemibrains were frozen on liquid nitrogen and cut in $20-\mu \mathrm{m}$-thick cryosections.

Activation and proliferation of microglia and astrocytes were assessed using immunostaining for CD45 and CD11b (1:500 dilution; Serotec, Oxford, UK), and glial fibrillary acidic protein (GFAP) (1:500 dilution; DakoCytomation, Glostrup, Denmark). Phospho-tau was analyzed using AT8 (Innogenetics, Gent, Belgium; 1:100 dilution) and AT100 (Innogenetics; 1:100 dilution) antibodies. Primary antibody binding was detected using either biotinylated secondary antibodies (1:200 dilution; Vector Laboratories, Burlingame, CA), avidin-biotin complex (Vectastain Elite kit; Vector Laboratories), and by reacting NiDAB (nickel diaminobenzidine) with $\mathrm{H}_{2} \mathrm{O}_{2}$ or by using Alexa Fluor 568-conjugated secondary antibody (1:200 dilution; Invitrogen, Eugene, OR). Human $\mathrm{A} \beta$ was detected with pan- $\mathrm{A} \beta$ antibody (1:200 dilution; BioSource, Nivelles, Belgium) followed with Alexa Fluor 568-conjugated secondary antibody (1:200 dilution; Invitrogen). The compact, fibrillar form of $A \beta$ was assessed by incubating the sections with $1 \%$ thioflavin in distilled $\mathrm{H}_{2} \mathrm{O}$ for $20 \mathrm{~min}$, followed by a quick rinse with water and dehydration through ascending series of alcohol before dipping in xylene and coverslipping.

Frontal cortical area from four to six sections in $200 \mu \mathrm{m}$ intervals through the hippocampi was evaluated per animal. For quantification of immunoreactive areas, the sections were imaged with an Olympus AX70 microscope (Olympus, Melville, NY) with an attached digital camera (Color View 12 or F-View; Soft Imaging System, Munster, Germany) running an Analysis Software (Soft Imaging System). All immunoreactive areas were quantified using ImagePro Plus software (Media Cybernetics, Silver Spring, MD). Data are expressed by area of hippocampi occupied by immunoreactivity and represented as the mean \pm SEM. The data were analyzed using Student's $t$ test, ANOVA, or a nonparametric test when appropriate in SPSS software, and statistical significance was assumed if $p<0.05$.

$A \beta_{1-40}$ and $A \beta_{1-42}$ ELISAs. The levels of $\mathrm{A} \beta_{1-40}$ and $\mathrm{A} \beta_{1-42}$ were analyzed by ELISA from freshly frozen hippocampal samples. For the analysis of soluble fraction of $A \beta$ species, the brain samples were homogenized in $7 \times$ volume of $20 \mathrm{~mm}$ Tris, $\mathrm{pH} 8.5$, containing complete inhibitory mixture (Roche Diagnostics, Mannheim, Germany). Samples were centrifuged for $1 \mathrm{~h}$ at $23,000 \mathrm{rpm}$ at $4^{\circ} \mathrm{C}$. Supernatant was taken for analysis of soluble fraction of $\mathrm{A} \beta$ species. To analyze insoluble fraction of $\mathrm{A} \beta$, the remaining pellet was resolved in guanidine buffer $(5.0 \mathrm{M}$ guanidine- $\mathrm{HCl} / 50$ mm Tris- $\mathrm{HCl}, \mathrm{pH}$ 8.0). The levels of $\mathrm{A} \beta 40$ and $\mathrm{A} \beta 42$ were quantified using Signal Select Beta Amyloid ELISA kits (BioSource) according to the manufacturer's protocol. The level of total $\mathrm{A} \beta_{1-40}$ and $\mathrm{A} \beta_{1-42}$ was standardized to brain tissue weight and expressed as nanograms of $A \beta$ per gram (brain tissue). The data were analyzed using Student's $t$ test in SPSS software, and statistical significance was assumed if $p<0.05$.

Measurement of copper concentration and markers of oxidative stress. 
Copper content of the freshly frozen cortical samples was detected from pyrolyzed samples by graphite furnace atomic absorption mass spectroscopy (Z-8100 Polarized Zeeman; Hitachi, Tokyo, Japan) at the City of Kuopio Environmental Health Laboratory.

Reduced glutathione (GSH) concentration in the tissue extracts was measured with 2,3naphthalenedicarboxaldehyde derivatization as described previously (Orwar et al., 1995). Superoxide dismutase 1 (SOD1) activity was measured from tissue homogenates by a previously described method (Beauchamp and Fridovich, 1971). Shortly, tissues were homogenized in a $10 \times$ volume of $20 \mathrm{~mm}$ Tris buffer, $\mathrm{pH}$ 7.4. After centrifugation for $5 \mathrm{~min}$ at $20,000 \times g$, SOD 1 activity was assayed from the supernatant. For detection of carbonylated proteins, cytosolic protein fractions separated from APP/PS1 and wt mouse brain samples were derivatized with 2 $\mathrm{mM}$ DNPH (2,4-dinitrophenylhydrazine) (Sigma, St. Louis, MO), precipitated, and dissolved as described previously (Korolainen et al., 2002) before running in SDS-PAGE with Mini Protean II to separate proteins for blotting them onto Hybond-P (APBiotech, Leicester, $\mathrm{UK}$ ) polyvinylidene difluoride (PVDF) membranes and staining with anti-DNP (2,4dinitrophenol) primary antibody (DakoCytomation) (Korolainen et al., 2002). The data were analyzed using Student's $t$ test or ANOVA when appropriate in SPSS software, and statistical significance was assumed if $p<0.05$.

Western blotting. The phosphorylation state of GSK-3 $\beta$ and Akt was detected by Western blotting using the following antibodies: antiphospho-Akt (pAkt-Ser473), anti-Akt, anti-phospho-GSK-3 $\beta$ (pGSK$3 \beta$-Ser9), and anti-GSK-3 $\beta$, all from Cell Signaling (Beverly, MA). GLT-1 antibody (Calbiochem, La Jolla, CA) was used to detect the possible upregulation of GLT-1 transporter. Briefly, the freshly frozen hippocampal brain samples were homogenized in $50 \mathrm{~mm}$ Tris, $\mathrm{pH} 7.4,150$ mм NaCl, 1 mм EGTA, 1 mм EDTA, 1\% NP-40, 1 mм Na $\mathrm{NO}_{4}$, and 20 $\mathrm{mm} \mathrm{NaF}$ containing complete protease inhibitor mixture (Roche Diagnostics). The samples were centrifuged for $20 \mathrm{~min}$ at 13,000 rpm, and the supernatant was mixed with standard Laemmli buffer and separated in $10 \%$ SDS-PAGE on Mini-Protean III electrophoresis device (Bio-Rad, Hercules, CA). After electrophoresis, proteins were transferred to a PVDF membrane (GE Healthcare) with a Mini-Protean II blotting cell (Bio-Rad) according to the manufacturer's instructions, and immunostained with the primary antibodies. This was followed by incubation with HRP-conjugated secondary antibodies and detection using ECL Plus kit (GE Healthcare). The bands were visualized using STORM 860 imager (GE Healthcare) and quantified with ImageQuant software (GE Healthcare). As a loading control, the membranes were blotted against actin (Sigma) and visualized by using Cy5-conjugated secondary antibody. The data were analyzed using Student's $t$ test in SPSS software, and statistical significance was assumed if $p<0.05$.

Hippocampal neuronal cultures and exposures to $A \beta$. Primary neuronal hippocampal cultures were made by dissecting hippocampi from embryonic day 18 mouse fetal brains. The cultures were prepared as described previously (Brewer et al., 1993). After dissociation, the cells were suspended in DMEM $/ 10 \%$ fetal bovine serum with penicillin-streptomycin (Invitrogen) and plated on a poly-ornithine-precoated $(0.5 \mu \mathrm{g} / \mu \mathrm{l}$; Sigma) 48-well culture plates. A total of 150,000 cells was plated per well, and the medium was changed to serum-free Neurobasal culture medium supplemented with $2 \% \mathrm{~B} 27,500 \mu \mathrm{M}$ glutamine, $25 \mu \mathrm{M}$ glutamate, and penicillin-streptomycin (Invitrogen). To obtain $\sim 90 \%$ pure neuronal culture, cells were treated with AraC (Sigma) at days 2-4 to prevent proliferation of other cell types. Three days later, one-third of the medium was changed.
C

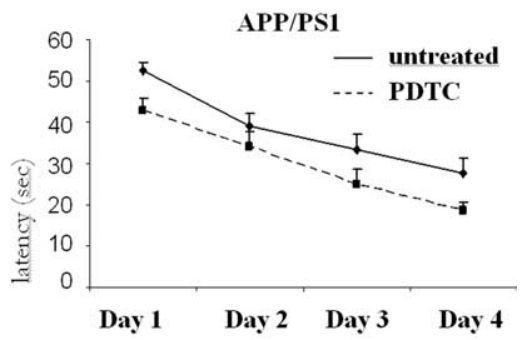

D

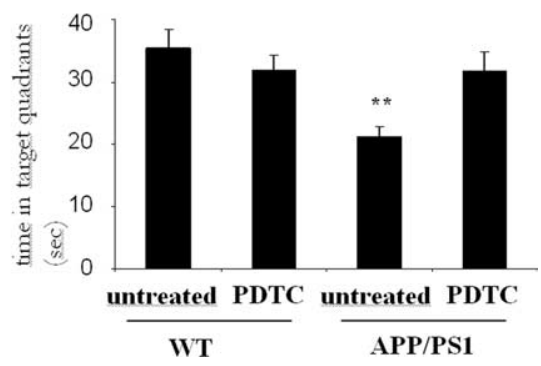

Figure 1. Long-term PDTC treatment prevented the cognitive decline of transgenic APP/PS1 mice. Test for acquisition was of tg mice. Two tg mice were excluded as statistical outliers, one in the control and one in the PDTC group. ${ }^{* *}$ Significantly different from the wt control ( $p=0.01$; Dunnett's post hoc test). The final numbers of the animals per each group were as follows: wt, 17; wt PDTC, 19; tg, 15; and tg PDTC, 13. Error bars indicate SEM.

$\mathrm{A} \beta_{1-42}$ was purchased from American Peptide (Sunnyvale, CA) and dissolved to a concentration of $1 \mathrm{mg} / \mathrm{ml}$ in sterile water. To obtain fibrillar $\mathrm{A} \beta$ preparation $\left(\mathrm{fA} \beta_{1-42}\right)$, the dissolved peptide was incubated at $37^{\circ} \mathrm{C}$ for $7 \mathrm{~d}$. For $\mathrm{A} \beta$ oligomer-rich preparation $\left(\mathrm{oA} \beta_{1-42}\right)$, the dissolved peptide was used immediately. Neurons were cotreated with freshly prepared oA $\beta_{1-42}$ or $\mathrm{fA} \beta_{1-42}$ at a concentration of $10 \mu \mathrm{M}$ and PDTC at a concentration of $1 \mu \mathrm{M}$ for $24 \mathrm{~h}$.

The form of $\mathrm{A} \beta$ preparations was analyzed by running $0.5 \mu \mathrm{g}$ of crosslinked [adapted from Levine (1995)] samples on a 18\% multiphasic buffer system SDS-PAGE gel as described previously (Wiltfang et al., 1997). After the run, the separated proteins were transferred onto PVDF membrane (GE Healthcare). A $\beta$ was detected using an antibody recognizing human $\mathrm{A} \beta$ (clone $6 \mathrm{E} 10 ; 1: 3000$ dilution; Signet, Dedham, MA) followed by secondary HRP-labeled anti-mouse antibody (GE Healthcare; 1:5000 dilution). The detection was done by ECL Plus kit (GE Healthcare), and the membranes were scanned on STORM 860 imager (GE Healthcare). Neurons exposed to $\mathrm{A} \beta_{1-42}$ and PDTC ( $n=3-4$ per group) were stained with Hoechst 33342, and viable neurons were counted under fluorescent microscope based on the absence of condensed chromatin.

\section{Results}

PDTC treatment markedly attenuates cognitive deficits of transgenic APP/PS1 mice

We first investigated whether a long-term, oral PDTC treatment reduces spatial learning deficits in transgenic APP/PS1 mice. The treatment was started at the age of 9 months when the first $\mathrm{A} \beta$ deposits had already developed. Tests for acquisition and a probe trial were performed after 7 months of treatment.

The ability of the mice to learn and process spatial information was tested by the Morris water maze. At the age of 16 months, $\operatorname{tg}$ mice demonstrated increased latency to locate the hidden platform (ANOVA with repeated measures; $F_{(1,68)}=7.0 ; p=0.01$ ) compared with wt mice (Fig. $1 A$ ). Because the effect of PDTC was dependent on the genotype (interaction nearly significant; $p=$ 
A

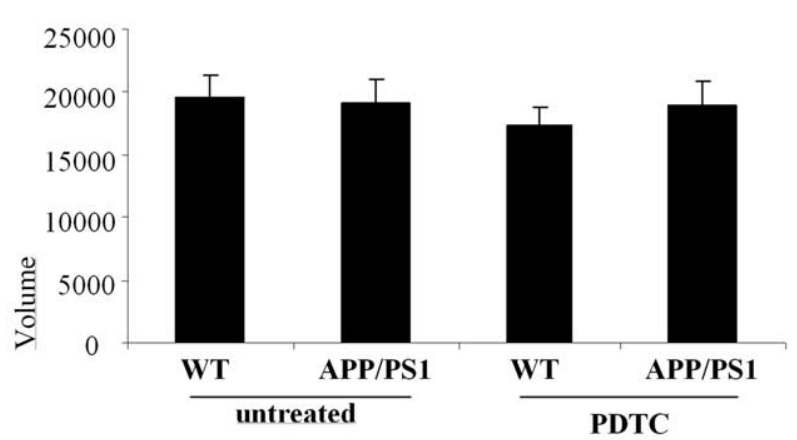

B

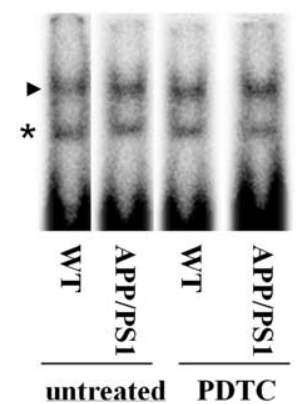

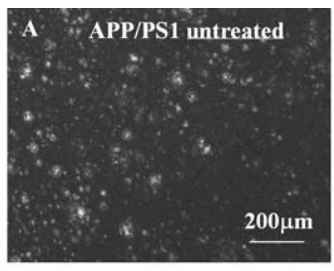
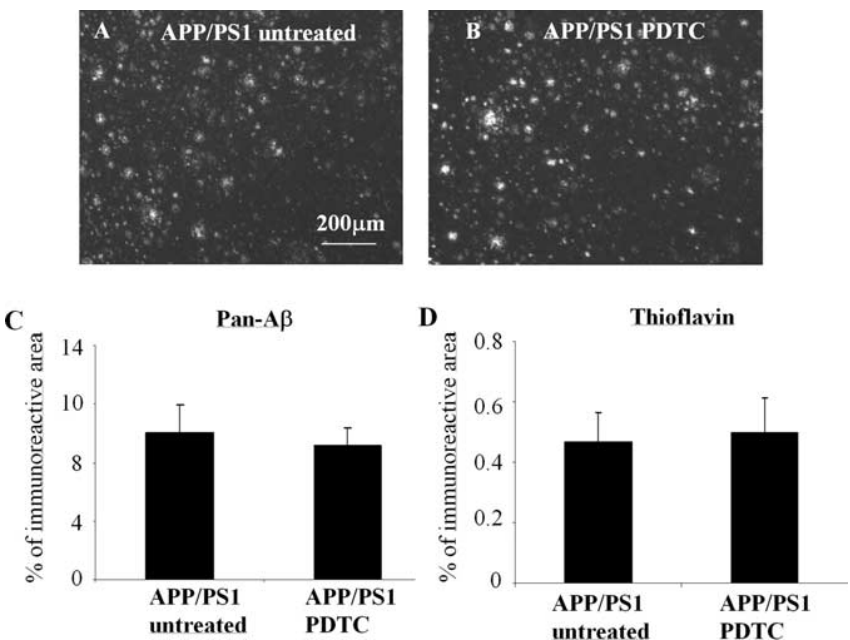

Figure 3. PDTC treatment had no effect on the brain $A \beta$ burden. The effect of PDTC treatment on the brain $A \beta$ burden was analyzed immunohistochemically by detecting diffuse $A \beta$ deposition using pan- $A \beta$ antibody staining and compact fibrillar plaques using thioflavin staining. The 16-month-old APP/PS1 mice exhibited extensive deposition of $A \beta$ in the cortex detected by pan- $A \beta$ antibody $(A)$; however, quantification revealed that PDTC treatment had no effect either on the pan- $A \beta$ immunoreactive areas $(\boldsymbol{B}, \boldsymbol{C})$ or thioflavin-stained area (D). Error bars indicate SEM.

Table 1. Effect of PDTC on the brain A $\beta$ levels as analyzed by ELISA

Figure 2. DNA binding activity of NF- $\kappa$ B was not altered in APP/PS1 mice nor affected by PDTC treatment. $\boldsymbol{A}, \boldsymbol{B}$, Quantitative analysis $(\boldsymbol{A})$ and a typical autoradiograph $(\boldsymbol{B})$ of electrophoretic mobility shift assay of the DNA binding activity of NF- $\kappa$ B in wt and APP/PS1 transgenic mouse brain. The assay did not reveal any alterations in the DNA binding activity of NF- $\kappa B$ in APP/PS1 mice compared with their water-treated controls. PDTC treatment did not have any effect on the DNA binding activities ( $n=8-10$ per group). Error bars indicate SEM. C shows the specificity of the NF- $\kappa B$ complex formation (arrowhead) in control mice. The lanes are as follows: (1) normal assay, (2) 100× unlabeled competitor (cold consensus probe), (3) labeled mutated NF- $\kappa$ B binding probe, (4) consensus probe without protein, (5) supershift assay with specific anti-p50, (6) supershift assay with anti-p65, and (7) supershift assay with anti-YY1. The arrowheads show the specific NF- $\kappa \mathrm{B}$ complex, the arrow shows the supershifted complex, and the asterisk shows the unspecific complex. The specific NF- $\kappa$ B complex contains both $p 50$ and p65 proteins.

0.055), wt and tg mice were evaluated separately. In wt mice, PDTC treatment had no effect (Fig. $1 B$ ); however, PDTC significantly improved learning of $\operatorname{tg}$ mice $\left(\mathrm{ANOVA}_{\mathrm{rm}} ; F_{(1,31)}=6.6\right.$; $p=0.015)$ as depicted in Figure 1C. The swimming speed did not differ between the groups $\left(\mathrm{ANOVA}_{\mathrm{rm}} ; F_{(3,68)}=2.0 ; p=0.12\right)$.

The last trial of day 4 was the probe trial. The platform was removed to test the tendency of an animal to search the platform from its previous correct location during a $60 \mathrm{~s}$ probe trial. Again, the ANOVA revealed impaired spatial memory of tg mice compared with their wt controls $\left(F_{(1,66)}=7.5 ; p=0.008\right)$. Similarly to the acquisition phase, the effect of PDTC was dependent on the genotype (genotype by drug interaction, $p=0.009$ ). No PDTC effect was observed in wt mice $\left(t_{(37)}=0.9 ; p=0.38\right)$, whereas it significantly enhanced search bias in $\operatorname{tg}$ mice $\left(t_{(29)}=3.3 ; p=\right.$ 0.003) (Fig. 1D).

\section{NF- $\kappa$ B and AP-1 DNA binding activities are not changed in} APP/PS1 mice and not affected by PDTC treatment

Because PDTC is known to be able to inhibit NF- $\kappa \mathrm{B}$, we run EMSA to detect the effect of PDTC on DNA binding activity of $\mathrm{NF}-\kappa \mathrm{B}$ in APP/PS1 tg and wt mice. EMSA revealed no differences in the DNA binding activity of NF- $\kappa$ B (Fig. 2) or AP-1 (data not shown) between untreated tg mice and their wt controls. PDTC

\begin{tabular}{lcc}
\hline & APP/PSI untreated & APP/PSI PDTC \\
\hline$A \beta_{1-42}$ soluble & $207.28 \pm 144.22$ & $236.64 \pm 154.72$ \\
$A \beta_{1-42}$ insoluble & $16,318 \pm 3754.70$ & $13,588.75 \pm 1859.30$ \\
$A \beta_{1-40}$ soluble & $85.67 \pm 32.16$ & $111.76 \pm 15.98$ \\
$A \beta_{1-40}$ insoluble & $7235 \pm 2359.26$ & $7001.5 \pm 2211.15$ \\
\hline
\end{tabular}

treatment did not significantly alter DNA binding activities of $\mathrm{NF}-\kappa \mathrm{B}$ or AP-1 in either wt or tg mice.

PDTC treatment has no effect on brain A $\beta$ burden, gliosis, or markers of oxidative stress in APP/PS1 mice

Antioxidants and antiinflammatories have been reported to reduce $\mathrm{A} \beta$ deposits or inhibit $\mathrm{A} \beta_{1-42}$ production (Cole et al., 2004; Lim et al., 2005; Townsend et al., 2005). We analyzed the brain $\mathrm{A} \beta$ burden by both immunohistochemistry and $\mathrm{A} \beta$ ELISA from the cortex and hippocampus. PDTC treatment did not decrease the cortical area covered by pan- $\mathrm{A} \beta$ immunoreactivity or the thioflavin-positive plaque load (Fig. 3). Also, PDTC had no effect on the hippocampal soluble or insoluble $\mathrm{A} \beta_{1-40}$ or $\mathrm{A} \beta_{1-42}$ levels as analyzed by ELISA (Table 1).

To investigate whether PDTC treatment has antiinflammatory effects by reducing gliosis in APP/PS1 mice, we assessed astrogliosis and microgliosis using GFAP as an astrocytic marker and CD45 and CD11b as microglia markers, respectively. All markers showed a clear increase of gliosis in untreated APP/PS1 mouse brain when compared with untreated wt controls (Fig. 4). However, PDTC treatment did not significantly alter GFAP, CD11b, or CD45 immunoreactivity in APP/PS1 mice or in wt controls as shown in Figure 4. Investigation of GFAP and CD45 immunoreactivities at 4 months of the PDTC treatment confirmed that no significant reductions in these general inflammatory markers (percentage of immunoreactive area: GFAP, tg untreated, $2.16 \pm 0.40 \%$, and tg PDTC treated, $1.94 \pm 0.12 \%, p>$ 0.05 , Student's $t$ test; CD45, tg untreated, $4.12 \pm 0.71 \%$, and tg PDTC treated, $3.67 \pm 0.44 \%, p>0.05$, Student's $t$ test; $N=4-6$ 
per group) were evident even at an earlier time point and before the observed changes in cognitive functions.

Oxidative stress is implicated in AD pathology, and several AD models display alterations in markers of oxidative stress, such as GSH, SOD1, and carbonylated proteins (Cole et al., 2004). However, we did not detect changes in these markers in APP/PS1 mice when compared with wt control mice, or with PDTC treatment (data not shown), suggesting that brain pathology in APP/PS1 mice does not involve marked oxidative damage.

Inactive pGSK-3 $\beta$-Ser9 is decreased in APP/PS1 mouse brain and PDTC treatment increases pGSK-3 $\beta$-Ser9 and active pAkt-Ser473

Because GSK-3 $\beta$ activity may play a role in $\mathrm{AD}$ and PDTC has been reported to interfere with Akt GSK-3 $\beta$ pathway, we determined the levels of inactive GSK-3 $\beta$ and active Akt in the mouse brains. Increased phosphorylation of Ser9 in GSK-3 $\beta$ reflects decreased activity of GSK-3 $\beta$, whereas phosphorylation of Akt in Ser473 reflects increased activity of Akt. Quantification of Western blots revealed that the amount of pGSK-3 $\beta$-Ser9 (Fig. $5 A$ ) but not pAkt-Ser473 (Fig. 6A) was significantly decreased in untreated APP/PS1 mice in the brain samples when compared with untreated wt animals. However, PDTC treatment significantly increased pAkt-Ser473 in APP/PS1 mice (by 60\%; $p<0.01$ ) (Fig. $6 B$ ) but not in wt mice (data not shown). In addition, pGSK- $3 \beta$ Ser9 levels in APP/PS1 mouse brain were significantly increased after PDTC treatment (Fig. 5B). These results indicate that the level of the active GSK- $3 \beta$ is increased in APP/PS1 mouse brains and that PDTC treatment increases the activity of protective Akt pathway. The increased levels of pGSK-3 $\beta$-Ser9 and pAkt-Ser473 were not attributable to an increase in total GSK-3 $\beta$ or total Akt, because the amount of total GSK- $3 \beta$ and total Akt was unchanged by PDTC treatment (Figs. 5,6 , respectively).

\section{PDTC treatment reduces phosphorylated tau in the hippocampus of APP/PS1 mice}

Because tau is a direct and relevant target of GSK- $3 \beta$ in AD, we determined the effect of PDTC on tau phosphorylation by using AT8 antibody, which detects the tau phosphorylated at Ser202, a target of many tau kinases including GSK-3 $\beta$; and AT100 antibody, which detects epitopes phospho-Ser212, a target of many tau kinases including GSK-3 $\beta$, and phospho-Thr214. AT8 stained strongly some short neurites that were associated with putative $\mathrm{A} \beta$ deposits in APP/PS1 mice (Fig. 7A-D). PDTC treatment had no clear effect on these AT8-immunoreactive, presumably dystrophic neurites. AT8 immunoreactivity was also ob-
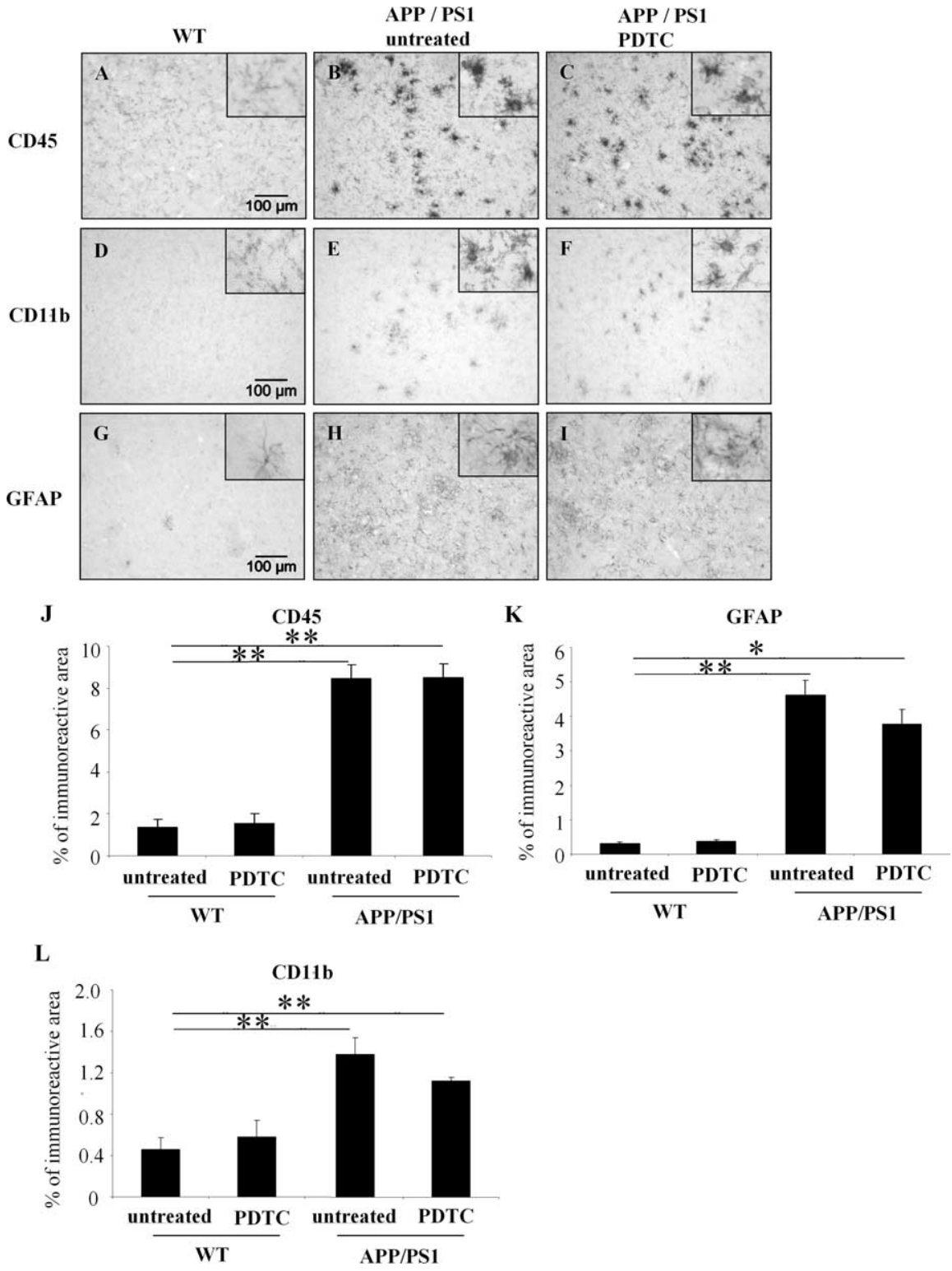

Figure 4. APP/PS1 mice exhibited markedly elevated gliosis which was not altered by PDTC treatment. Immunohistochemistry revealed significant gliosis as analyzed by microglial markers CD11b, CD45, and an astrocytic marker GFAP. $A$, D, and G show CD45, high-power insets show typical morphology of stained glial cells. The quantification of each of the staining is shown in graphs $J-L$. Error bars indicate SEM. ${ }^{*} p<0.05 ;{ }^{* *} p<0.01$.

served in region-specific neuronal cell bodies, especially in the CA3 pyramidal cells (Fig. $7 E-H)$, in which quantification revealed that cytosolic AT8 immunoreactivity was $66 \%$ greater in untreated APP/PS1 mice $(8.3 \pm 1.9 \%$ area covered by immunoreactivity) than in untreated wt mice $(5.0 \pm 1.0 \%)$. PDTC treatment had no effect on the AT8 immunoreactivity of these cells in wt mice, but significantly decreased the AT8 immunoreactivity in APP/PS1 mice by $80 \%$ (to $1.7 \pm 0.4 \% ; p<0.01$ ). AT100 antibody stained neuronal cell bodies in the cortex and CA3 neurons, as well as dystrophic neurites around the plaques. Quantitative analysis of AT100 immunostaining in the CA3 pyramidal cells showed a trend but not a statistically significant reduction in PDTC-treated versus untreated in APP/PS1 mice (percentage of immunoreactive area: $2.56 \pm 0.48$ and $3.87 \pm 1.58 \%$ in PDTCtreated and untreated tg mice, respectively; $N=5$ per group; $p=$ 


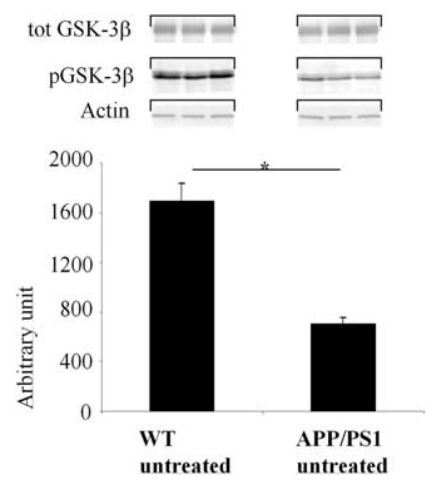

B
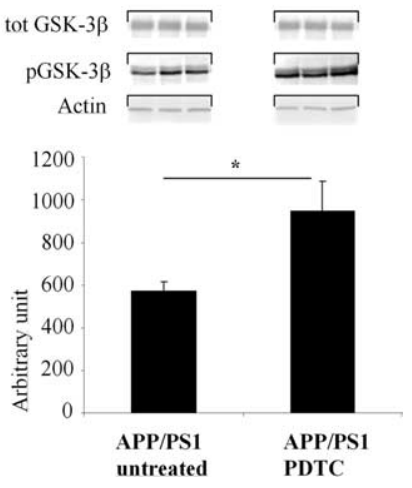

Figure 5. PDTC treatment increased phosphorylation of GSK-3 $\beta$-Ser9. An illustration of typical immunoblots with antibodies against pGSK-3 $\beta$-Ser9 and total GSK- $3 \beta$ and their subsequent quantification showed that the level of pGSK-3 $\beta$-Ser9 was decreased in APP/PS1 mice compared with wt mice $(\boldsymbol{A})$ and that PDTC treatment significantly increased the levels of pGSK$3 \beta$-Ser9 in APP/PS1 mouse brain $(\boldsymbol{B})$. The differences in the level of $\mathrm{pGSK}-3 \beta$-Ser9 were not attributable to changes in total $p G S K-3 \beta$, because the amount of total GSK-3 $\beta$ remained unchanged. Membranes were blotted against actin as a loading control. Error bars indicate SEM. ${ }^{*} p<0.05$.
A

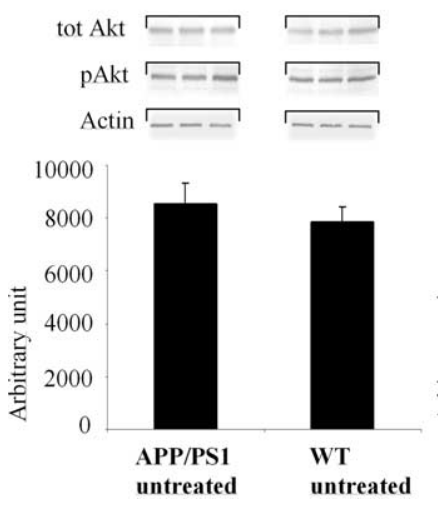

B
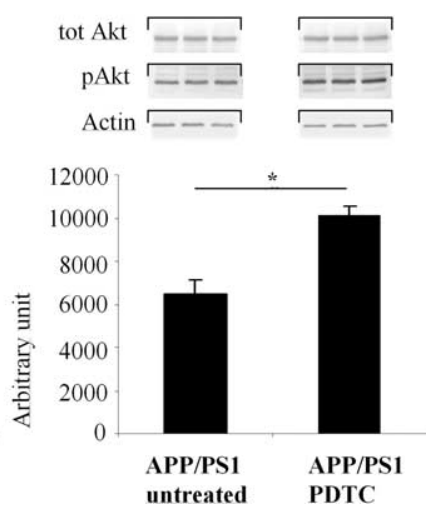

Figure 6. PDTC treatment increased phosphorylation of pAkt-Ser473. $A, A P P / P S 1$ mice had similar levels of pAkt-Ser473 compared with untreated wt mice. $\boldsymbol{B}$, However, PDTC treatment significantly increased the levels of pAkt-Ser473. This increase was independent of the amount of total Akt, which remained unchanged in all animals. The membranes were blotted against actin as a loading control. Error bars indicate SEM. ${ }^{*} p<0.05$.

0.07 , Student's $t$ test), possibly because only one epitope of the AT100 antibody may be a target of GSK-3 $\beta$. Overall, these results suggest, although do not prove, that the PDTC-induced increase in the active Akt and reduction in the active GSK- $3 \beta$ may occur at least partially in neurons.

\section{PDTC treatment upregulates the reduced GLT-1 levels in}

\section{APP/PS1 mouse brain}

Because defects in uptake of glutamate through glial glutamate transporter GLT-1 have been reported in $\mathrm{AD}$ and in $\mathrm{A} \beta$-treated cultured astrocytes (Harris et al., 1996; Masliah et al., 2000; Liang et al., 2002) and the expression of GLT-1 is regulated by Akt pathway (Li et al., 2006), we determined the changes in GLT-1 in our experimental settings by Western blotting. The cortical GLT-1 levels were 18\% lower in untreated APP/PS1 mice compared with untreated wt mice (Fig. $8 A$ ). PDTC treatment increased GLT-1 levels by $24 \%(p<0.05)$ in APP/PS1 mice (Fig. $8 B$ ) but had no effect on GLT-1 in wt mice (data not shown).
These results suggest that PDTC treatment increases the amount of active Akt in astrocytes and thereby increases GLT-1 levels.

PDTC increases brain copper concentration in APP/PS1 mice Because $\mathrm{Cu}^{2+}$ has been reported to activate Akt (Ostrakhovitch et al., 2002), and PDTC is a metal chelator capable of transferring external $\mathrm{Cu}^{2+}$ into a cell (Verhaegh et al., 1997), we measured the brain copper concentrations from the cortical samples by atomic absorption spectrophotometer. Whereas no difference in the copper concentration between the untreated APP/PS1 and wt mice was observed, PDTC treatment increased copper concentration in APP/PS1 by 26\% ( $p<0.05)$ (Fig. 9).

\section{PDTC protects hippocampal neurons against oligomer-rich $\mathrm{A} \boldsymbol{\beta}$ but not fibrillar $\mathrm{A} \boldsymbol{\beta}$}

To test whether PDTC protects directly neurons against $\mathrm{A} \beta_{1-42^{-}}$ induced injury and whether PDTC has differential effect on neurotoxicity induced by $\mathrm{A} \beta$ oligomers and fibrillar $\mathrm{A} \beta$, we run cell culture experiments on primary hippocampal neurons. The neuronal purity of these cultures is $94 \%$. Western blot analysis revealed that the oA $\beta_{1-42}$ preparation contained monomeric, various forms of oligomeric and small amount of high-molecularweight forms of $A \beta$ that moved very little on the gel. Fibrillization of $\mathrm{A} \beta\left(\mathrm{fA} \beta_{1-42}\right)$ resulted in high-molecular-weight aggregates that did not move on gel at all (Fig. 10A).

oA $\beta_{1-42}$ caused $\sim 40 \%$ cell death after 24 h exposure (Fig. $10 \mathrm{~B})$. Cotreatment of neurons with $1 \mu \mathrm{M}$ PDTC significantly, although not completely, protected the cells against $\mathrm{A} \beta$ toxicity. $\mathrm{oA} \beta_{1-42}$ was significantly more toxic compared with fA $\beta_{1-42}$, which caused only $\sim 20 \%$ neuron death. PDTC failed to prevent any toxicity caused by fibrillar A $\beta$. PDTC alone did affect the neuronal viability.

\section{Discussion}

Our results showed that PDTC, a clinically tolerated dithiocarbamate capable of crossing the blood-brain barrier (Frank et al., 1995; Nurmi, 2004), markedly prevented or cured the cognitive deficits in aged APP/PS1 tg mice. This beneficial effect of PDTC was seen when the treatment was started after the first $A \beta$ deposits had already developed. Because brain $\mathrm{A} \beta$ burden and gliosis were unaltered by the treatment and the cell culture experiments showed that PDTC provides protection against oligomer-rich $\mathrm{A} \beta_{1-42}$ preparation but not fibrillar $\mathrm{A} \beta_{1-42}$ preparation, it is likely that the effect of PDTC was based on prevention of the $\mathrm{A} \beta$ oligomer-mediated neuronal dysfunction, which involves activation of GSK-3 $\beta$. Considering that antiinflammatories and antioxidants typically reduce both the $\mathrm{A} \beta$ burden and gliosis in animal models of AD (Jantzen et al., 2002; Cole et al., 2004; Lim et al., 2005; Townsend and Pratico, 2005), and that NF- $\kappa$ B activity and markers of oxidative stress were not induced in our APP/PS1 mice at the age 16 months, it is very likely that the beneficial effect of PDTC is only marginally if at all based on its potential antioxidative and antiinflammatory effects. Instead, in agreement with previous studies on human $\mathrm{AD}$ and $\mathrm{AD}$ mouse models, we found that the inactive form of GSK-3 $\beta$ was decreased in APP/PS1 mouse brain and that PDTC treatment increased the active form of Akt and upregulated the inactive pGSK-3 $\beta$-Ser9. Although the methodology we used to determine the GSK-3 $\beta$ activation has certain limitations, it is conceivable that the improved spatial learning can be attributed to the PDTC-induced activation of Akt pathway (Pei et al., 1997, 1999). This suggestion is in line with the previous studies showing (1) that spatial learning deficits are regulated by conditionally overexpressed GSK-3 $\beta$ in the mouse 
brain (Hernandez et al., 2002; Engel et al., 2006), (2) that mutant presenilins can activate GSK-3 $\beta$ (Weihl et al., 1999), (3) that activation of Akt pathway is necessary for the expression of long-term potentiation (Sanna et al., 2002; Karpova et al., 2006), and (4) that inhibitors of Akt pathway impair long-term consolidation and recognition memory in rats (Horwood et al., 2006). Moreover, cerebrolysin (a mixture of peptides and amino acids obtained from porcine brain tissue), PPAR $\gamma$ (peroxisome proliferator-activated receptor- $\gamma$ ) agonists, and the $\mathrm{A} \beta$ antibodies that ameliorate behavioral deficits in transgenic $\mathrm{AD}$ mice or $\mathrm{AD}$ have also potential to decrease GSK-3 $\beta$ activation (Inestrosa et al., 2005; Watson et al., 2005; Ma et al., 2006; Rockenstein et al., 2006; Sastre et al., 2006).

In agreement with the hypothesis that Akt pathway is induced by PDTC treatment, we observed decreased immunoreactivity for phosphorylated tau in the CA3 pyramidal neurons and overall increase in GLT-1, a major astrocytic glutamate transporter that has previously been reported to be reduced in AD models (Harris et al., 1996; Masliah et al., 2000; Liang et al., 2002). Although GSK-3 $\beta$ is responsible for phosphorylating Ser202 (Mandelkow et al., 1992; Ishiguro et al., 1993), the major site for abnormal phosphorylation of tau resulting in formation of paired helical filaments (PHFs) in AD (Ikura et al., 1998), it is uncertain whether the PDTC-induced reduction we observed in Ser202 phosphorylation (AT8 immunoreactivity) contributes to the improved cognitive functions, because PHFs cannot be found in transgenic APP or APP/PS1 mice and we could not detect reduction in AT8-immunoreactive dystrophic neurites around $\mathrm{A} \beta$ deposits. We also observed a tendency for decreased tau phosphorylation in PDTC-treated APP/PS1 mice by using AT100 antibody, which detects phosphorylation of Ser212 (a target of several kinases, including GSK-3 $\beta$ ) and Thr214, supporting the notion that PDTC affects GSK-3 $\beta$ activity in neurons of APP/PS1 mice. Similarly, although Akt pathway is known to control the expression of GLT-1 (Li et al., 2006), which is necessary for normal LTP and maintaining glutamate at nontoxic concentration (Hatten et al., 1991; Sanna et al., 2002), it is uncertain whether the increased GLT-1 levels we observed after PDTC treatment in APP/PS1 mice is sufficient or needed for the recovery of cognitive functions. Nevertheless, our findings perfectly support the hypothesis that PDTC treatment activated Akt-GSK-3 $\beta$ pathway both in neurons and astrocytes with functional consequences that have relevance in $\mathrm{AD}$ pathology. Furthermore, although not relevant for cognitive functions in this AD mouse model, these effects of PDTC are potentially beneficial in human $\mathrm{AD}$, in which PHFs correlate with cognitive deficits (Giannakopoulos et al., 2003).

Several studies have linked copper ions with $\mathrm{AD}$. Serum $\mathrm{Cu}^{2+}$ levels in AD patients are increased (Squitti et al., 2002), senile plaques in $\mathrm{AD}$ brain are enriched with copper ions (Lovell et al., 1998), $\mathrm{Cu}^{2+}$ may increase $\beta$-sheet formation of $\mathrm{A} \beta$ (Miura et al., 2004 ), and $\mathrm{Cu}^{2+}$ enhances $\mathrm{A} \beta$ neurotoxicity in some cell culture studies (Huang et al., 1999; Opazo et al., 2002). Moreover, some copper chelators, such as clioquinol, partially dissemble $\mathrm{A} \beta$ deposits in transgenic AD models (Cherny et al., 2001; Lee et al., 2004). However, APP and A $\beta$ overproduction enables intracellu-
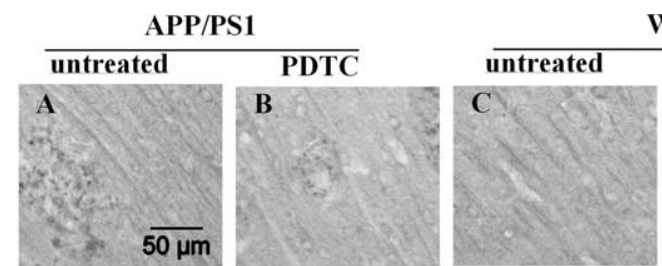

WT
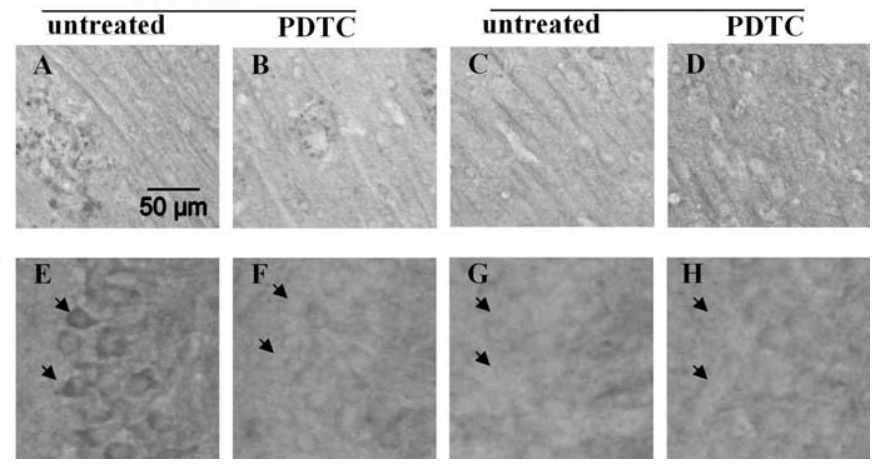

reduced the amount of phosphorylated tau in the hippocampus CA3 region of APP/PS1 mice. Photomicrographs showing AT8 immunoreactivity in the cortex $(\boldsymbol{A}-\boldsymbol{D})$ and CA3 pyramical cells $(\boldsymbol{E}-\boldsymbol{H})$ of wt and APP/PS1 mouse brains. $A$, AT8 immunoreactivity was observed surrounding putative $A \beta$ deposits in the cortical areas of APP/PS1 mice, presumably reflecting dystrophic neurites. $\boldsymbol{B}-\boldsymbol{D}$, This staining was not clearly altered by PDTC treatment $(\boldsymbol{B})$ and was absent in wt mice (C, E-H, High-power insets show AT8 immunoreactivity observed in the hippocampal CA3 region (arrow) pyramidal cells (arrow-

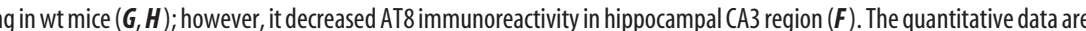

A

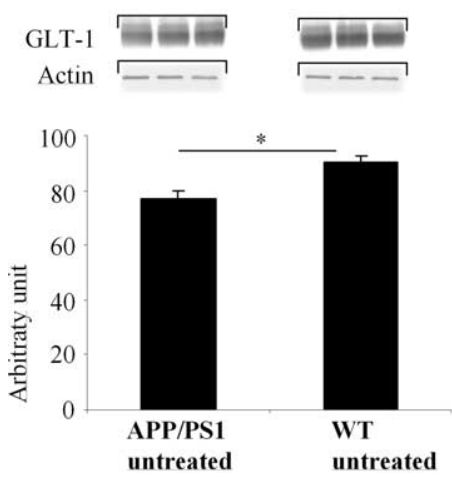

B

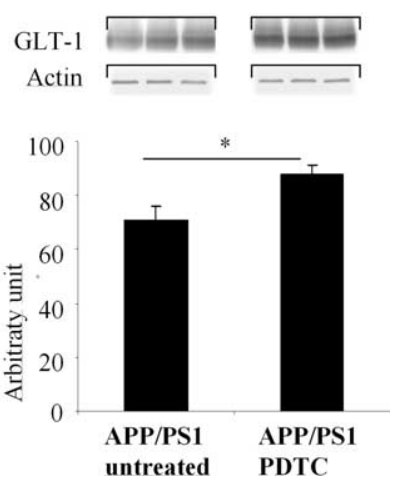

Figure 8. PDTC treatment increased the levels of astrocytic GLT-1. APP/PS1 mice exhibited a significant decrease in the level of astrocytic receptor GLT-1 $(\boldsymbol{A})$. PDTC treatment significantly increased the levels of GLT-1, bringing it back to normal as depicted in $\boldsymbol{B}$. The membranes were blotted against actin as a loading control. Error bars indicate SEM. ${ }^{*} p<0.05$.

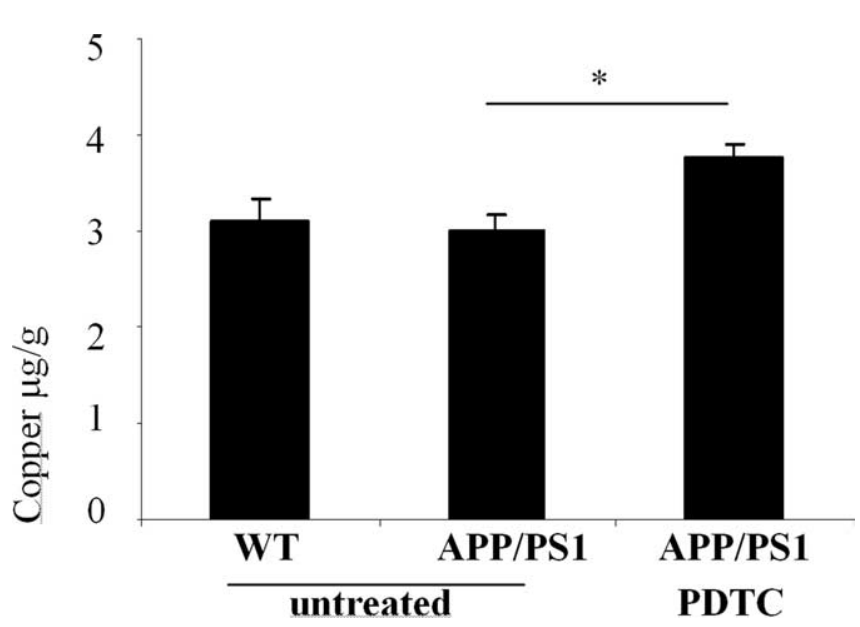

Figure 9. PDTC treatment increased the cortical copper concentration. Untreated APP/PS1 and wt mice exhibited a similar amount of copper in the cortex as measured by atomic absorption spectophotometer. Long-term PDTC treatment significantly increased the copper concentration in APP/PS1 mice. Error bars indicate SEM. ${ }^{*} p<0.05$. 
A

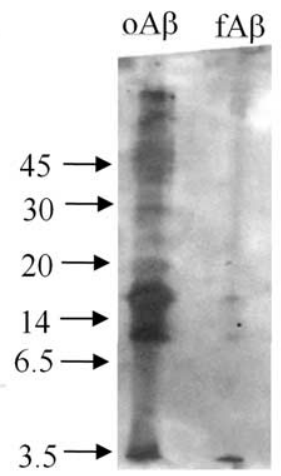

B

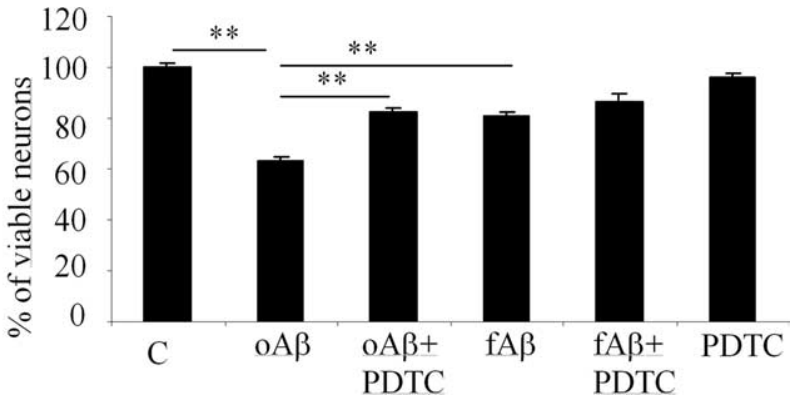

Figure 10. PDTC protected primary hippocampal neurons against oligomer-rich $A \beta$ induced toxicity. $A$, Freshly dissolved $A \beta$ preparation contained mostly oligomers, ranging from monomeric $A \beta$ to high-molecular-weight forms. Fibrillization of $A \beta$ resulted predominantly in high-molecular-weight aggregates that did not penetrate into the SDS-PAGE gel used in the current study. $B$, Exposure of primary hippocampal neurons to the freshly dissolved, oligomer-rich $A \beta$ preparation caused $\sim 40 \%$ cell death as analyzed by the appearance of condensed chromatin. The cell death was significantly diminished by cotreatment with 1 $\mu \mathrm{M}$ PDTC. Fibrillar $\mathrm{A} \beta$ was also toxic causing $\sim 20 \%$ cell death, although the effect was significantly smaller compared with oligomer-rich preparation. PDTC failed to protect the neurons against fibrillar A $\beta$ toxicity. PDTC alone did not affect the cell viability. Error bars indicate SEM. ${ }^{*} p<0.01$.

lar copper to be transported out of the cell, leading to cellular copper insufficiency, and under certain conditions, $\mathrm{A} \beta$-copper complexes are neuroprotective (Maynard et al., 2002; Bayer et al., 2003; Phinney et al., 2003). Moreover, copper deficiency may lead to reduced activity of Cu,Zn-SOD1 (Bayer et al., 2003), a major cytoplasmic antioxidant, and thereby alter endogenous antioxidant defense system, including possible SOD1-induced activation of Akt (Noshita et al., 2003). Overall, copper homeostasis may be disturbed in $\mathrm{AD}$, and the functions of $\mathrm{Cu}^{2+}$ in $\mathrm{AD}$ pathogenesis appear to be complicated. Whereas the brain copper concentrations in APP/PS1 and wt mice were statistically the same in our study, PDTC treatment significantly increased copper levels in APP/PS1 mouse brains. PDTC is a $\mathrm{Cu}^{2+}$ chelator capable of transferring external $\mathrm{Cu}^{2+}$ into a cell (Verhaegh et al., 1997), suggesting that PDTC-increased concentration of copper may be attributable to increased intracellular $\mathrm{Cu}^{2+}$. PDTC treatment could thus alter the ratio of extracellular and intracellular copper, and compensate the $\mathrm{A} \beta$-induced reduction in intracellular $\mathrm{Cu}^{2+}$. Because $\mathrm{Cu}^{2+}$ can also activate Akt (Ostrakhovitch et al., 2002), we hypothesize that PDTC-induced increase in intracellular $\mathrm{Cu}^{2+}$ triggers Akt phosphorylation, leading to decreased activity of GSK-3 $\beta$, reduced tau phosphorylation, increased GLT-1 expression, and activation of cell survival supporting functions of Akt pathway. This hypothesis does not exclude the possibility that other copper-dependent functions may also contribute to the improved cognitive functions in PDTC-treated $\mathrm{APP} / \mathrm{PS} 1$ mice. An interesting finding is that $\mathrm{A} \beta$ peptides may bind copper (Curtain et al., 2001; Zou et al., 2002), thereby possibly causing some pathological effects. Whether PDTC binds and prevents metal binding of $A \beta$ peptides is not known.

It is unclear why PDTC treatment caused changes in Akt pathway in APP/PS1 but not in wt mice. Several changes in cellular functions are triggered by mutant PS1 and APP that may alter the response of neurons and astrocytes to PDTC, including mutant PS1 and intracellular A $\beta$ themselves, which are able to inhibit activation of Akt pathway (Baki et al., 2004; Magrane et al., 2005). In addition, inflammatory mediators induced in APP/PS1 mouse brain may regulate Akt (Grzelkowska-Kowalczyk and WieteskaSkrzeczynska, 2006). It may be possible that APP/PS1 pathology results in compensatory promotion of Akt pathway to maintain it

at normal levels, and that an additional Akt activating signal, such as PDTC or $\mathrm{Cu}^{2+}$, then results in additional activation of Akt. One may also speculate that PDTC or $\mathrm{Cu}^{2+}$ form such complexes with $\mathrm{A} \beta$ that have high impact on Akt pathway. However, there is no experimental evidence for this hypothesis. Nevertheless, the fact that Akt, GSK-3 $\beta$, tau, or GLT-1 were not significantly altered in wt mouse brain by PDTC treatment suggests that the overall effects of PDTC may be milder in healthy brain and that PDTC treatment, at the low doses used in the present study, may affect only disturbed cellular functions and cause relatively few adverse effects. In agreement with this idea, we did not observe any side effects or changes in the body weight in our PDTC-treated mice. Because diothiocarbamates are relatively well tolerated in humans, and PDTC has several potentially beneficial effects on neurodegeneration processes, our observation of improved cognitive function in a relevant animal model of AD warrants additional studies on PDTC and its analogs toward clinical trials.

\section{References}

Akiyama H, Barger S, Barnum S, Bradt B, Bauer J, Cole GM, Cooper NR, Eikelenboom P, Emmerling M, Fiebich BL, Finch CE, Frautschy S, Griffin WS, Hampel H, Hull M, Landreth G, Lue L, Mrak R, Mackenzie IR, McGeer PL, et al. (2000) Inflammation and Alzheimer's disease. Neurobiol Aging 21:383-421.

Anderson AJ, Su JH, Cotman CW (1996) DNA damage and apoptosis in Alzheimer's disease: colocalization with c-Jun immunoreactivity, relationship to brain area, and effect of postmortem delay. J Neurosci 16:1710-1719.

Baki L, Shioi J, Wen P, Shao Z, Schwarzman A, Gama-Sosa M, Neve R, Robakis NK (2004) PS1 activates PI3K thus inhibiting GSK-3 activity and tau overphosphorylation: effects of FAD mutations. EMBO J 23:2586-2596.

Bayer TA, Schafer S, Simons A, Kemmling A, Kamer T, Tepest R, Eckert A, Schussel K, Eikenberg O, Sturchler-Pierrat C, Abramowski D, Staufenbiel M, Multhaup G (2003) Dietary Cu stabilizes brain superoxide dismutase 1 activity and reduces amyloid Abeta production in APP23 transgenic mice. Proc Natl Acad Sci USA 100:14187-14192.

Beach TG, Kuo YM, Spiegel K, Emmerling MR, Sue LI, Kokjohn K, Roher AE (2000) The cholinergic deficit coincides with Abeta deposition at the earliest histopathologic stages of Alzheimer disease. J Neuropathol Exp Neurol 59:308-313.

Beauchamp C, Fridovich I (1971) Superoxide dismutase: improved assays and an assay applicable to acrylamide gels. Anal Biochem 44:276-287.

Behl C, Davis JB, Lesley R, Schubert D (1994) Hydrogen peroxide mediates amyloid beta protein toxicity. Cell 77:817-827.

Brewer GJ, Torricelli JR, Evege EK, Price PJ (1993) Optimized survival of hippocampal neurons in B27-supplemented Neurobasal, a new serumfree medium combination. J Neurosci Res 35:567-576.

Busciglio J, Lorenzo A, Yeh J, Yankner BA (1995) Beta-amyloid fibrils induce tau phosphorylation and loss of microtubule binding. Neuron 14:879-888.

Cherny RA, Atwood CS, Xilinas ME, Gray DN, Jones WD, McLean CA, Barnham KJ, Volitakis I, Fraser FW, Kim Y, Huang X, Goldstein LE, Moir RD, Lim JT, Beyreuther K, Zheng H, Tanzi RE, Masters CL, Bush AI (2001) Treatment with a copper-zinc chelator markedly and rapidly inhibits beta-amyloid accumulation in Alzheimer's disease transgenic mice. Neuron 30:665-676.

Cole GM, Morihara T, Lim GP, Yang F, Begum A, Frautschy SA (2004) NSAID and antioxidant prevention of Alzheimer's disease: lessons from in vitro and animal models. Ann NY Acad Sci 1035:68-84. 
Curtain CC, Ali F, Volitakis I, Cherny RA, Norton RS, Beyreuther K, Barrow CJ, Masters CL, Bush AI, Barnham KJ (2001) Alzheimer's disease amyloid-beta binds copper and zinc to generate an allosterically ordered membrane-penetrating structure containing superoxide dismutase-like subunits. J Biol Chem 276:20466-20473.

Davies P, Maloney AJ (1976) Selective loss of central cholinergic neurons in Alzheimer's disease. Lancet 2:1403.

Dignam JD, Lebovitz RM, Roeder RG (1983) Accurate transcription initiation by RNA polymerase II in a soluble extract from isolated mammalian nuclei. Nucleic Acids Res 11:1475-1489.

Engel T, Hernandez F, Avila J, Lucas JJ (2006) Full reversal of Alzheimer's disease-like phenotype in a mouse model with conditional overexpression of glycogen synthase kinase-3. J Neurosci 26:5083-5090.

Estus S, Tucker HM, van Rooyen C, Wright S, Brigham EF, Wogulis M, Rydel RE (1997) Aggregated amyloid- $\beta$ protein induces cortical neuronal apoptosis and concomitant "apoptotic" pattern of gene induction. J Neurosci 17:7736-7745.

Frank N, Christmann A, Frei E (1995) Comparative studies on the pharmacokinetics of hydrophilic prolinedithiocarbamate, sarcosinedithiocarbamate and the less hydrophilic diethyldithiocarbamate. Toxicology 95:113-122.

Giannakopoulos P, Herrmann FR, Bussiere T, Bouras C, Kovari E, Perl DP, Morrison JH, Gold G, Hof PR (2003) Tangle and neuron numbers, but not amyloid load, predict cognitive status in Alzheimer's disease. Neurology 60:1495-1500.

Goodman Y, Mattson MP (1994) Secreted forms of beta-amyloid precursor protein protect hippocampal neurons against amyloid beta-peptideinduced oxidative injury. Exp Neurol 128:1-12.

Grimes CA, Jope RS (2001) The multifaceted roles of glycogen synthase kinase 3beta in cellular signaling. Prog Neurobiol 65:391-426.

Grzelkowska-Kowalczyk K, Wieteska-Skrzeczynska W (2006) Exposure to TNF-alpha but not IL-1beta impairs insulin-dependent phosphorylation of protein kinase B and p70S6k in mouse C2C12 myogenic cells. Pol J Vet Sci 9:1-10.

Harris ME, Wang Y, Pedigo Jr NW, Hensley K, Butterfield DA, Carney JM (1996) Amyloid beta peptide (25-35) inhibits $\mathrm{Na}^{+}$-dependent glutamate uptake in rat hippocampal astrocyte cultures. J Neurochem 67:277-286

Hatten ME, Liem RK, Shelanski ML, Mason CA (1991) Astroglia in CNS injury. Glia 4:233-243.

Hayakawa M, Miyashita H, Sakamoto I, Kitagawa M, Tanaka H, Yasuda H, Karin M, Kikugawa K (2003) Evidence that reactive oxygen species do not mediate NF-kappaB activation. EMBO J 22:3356-3366.

Helenius M, Hanninen M, Lehtinen SK, Salminen A (1996) Changes associated with aging and replicative senescence in the regulation of transcription factor nuclear factor-kappa B. Biochem J 318:603-608.

Hernandez F, Borrell J, Guaza C, Avila J, Lucas JJ (2002) Spatial learning deficit in transgenic mice that conditionally over-express GSK-3beta in the brain but do not form tau filaments. J Neurochem 83:1529-1533.

Horwood JM, Dufour F, Laroche S, Davis S (2006) Signalling mechanisms mediated by the phosphoinositide 3-kinase/Akt cascade in synaptic plasticity and memory in the rat. Eur J Neurosci 23:3375-3384.

Huang X, Cuajungco MP, Atwood CS, Hartshorn MA, Tyndall JD, Hanson GR, Stokes KC, Leopold M, Multhaup G, Goldstein LE, Scarpa RC, Saunders AJ, Lim J, Moir RD, Glabe C, Bowden EF, Masters CL, Fairlie DP, Tanzi RE, Bush AI (1999) Cu(II) potentiation of alzheimer abeta neurotoxicity. Correlation with cell-free hydrogen peroxide production and metal reduction. J Biol Chem 274:37111-37116.

Hye A, Kerr F, Archer N, Foy C, Poppe M, Brown R, Hamilton G, Powell J, Anderton B, Lovestone S (2005) Glycogen synthase kinase-3 is increased in white cells early in Alzheimer's disease. Neurosci Lett 373:1-4.

Ikura Y, Kudo T, Tanaka T, Tanii H, Grundke-Iqbal I, Iqbal K, Takeda M (1998) Levels of tau phosphorylation at different sites in Alzheimer disease brain. NeuroReport 9:2375-2379.

Inestrosa NC, Godoy JA, Quintanilla RA, Koenig CS, Bronfman M (2005) Peroxisome proliferator-activated receptor gamma is expressed in hippocampal neurons and its activation prevents beta-amyloid neurodegeneration: role of Wnt signaling. Exp Cell Res 304:91-104.

Ishiguro K, Shiratsuchi A, Sato S, Omori A, Arioka M, Kobayashi S, Uchida T, Imahori K (1993) Glycogen synthase kinase 3 beta is identical to tau protein kinase I generating several epitopes of paired helical filaments. FEBS Lett 325:167-172.
Jankowsky JL, Fadale DJ, Anderson J, Xu GM, Gonzales V, Jenkins NA, Copeland NG, Lee MK, Younkin LH, Wagner SL, Younkin SG, Borchelt DR (2004) Mutant presenilins specifically elevate the levels of the 42 residue beta-amyloid peptide in vivo: evidence for augmentation of a 42-specific gamma secretase. Hum Mol Genet 13:159-170.

Jantzen PT, Connor KE, DiCarlo G, Wenk GL, Wallace JL, Rojiani AM, Coppola D, Morgan D, Gordon MN (2002) Microglial activation and $\beta$-amyloid deposit reduction caused by a nitric oxide-releasing nonsteroidal anti-inflammatory drug in amyloid precursor protein plus presenilin-1 transgenic mice. J Neurosci 22:2246-2254.

Karpova A, Sanna PP, Behnisch T (2006) Involvement of multiple phosphatidylinositol 3-kinase-dependent pathways in the persistence of latephase long term potentiation expression. Neuroscience 137:833-841.

Koistinaho M, Kettunen MI, Goldsteins G, Keinanen R, Salminen A, Ort M, Bures J, Liu D, Kauppinen RA, Higgins LS, Koistinaho J (2002) Betaamyloid precursor protein transgenic mice that harbor diffuse A beta deposits but do not form plaques show increased ischemic vulnerability: role of inflammation. Proc Natl Acad Sci USA 99:1610-1615.

Korolainen MA, Goldsteins G, Alafuzoff I, Koistinaho J, Pirttila T (2002) Proteomic analysis of protein oxidation in Alzheimer's disease brain. Electrophoresis 23:3428-3433.

La Rosa G, Cardali S, Genovese T, Conti A, Di Paola R, La Torre D, Cacciola F, Cuzzocrea S (2004) Inhibition of the nuclear factor-kappaB activation with pyrrolidine dithiocarbamate attenuating inflammation and oxidative stress after experimental spinal cord trauma in rats. J Neurosurg Spine 1:311-321.

Lauderback CM, Hackett JM, Huang FF, Keller JN, Szweda LI, Markesbery WR, Butterfield DA (2001) The glial glutamate transporter, GLT-1, is oxidatively modified by 4-hydroxy-2-nonenal in the Alzheimer's disease brain: the role of Abeta1-42. J Neurochem 78:413-416.

Lee JY, Friedman JE, Angel I, Kozak A, Koh JY (2004) The lipophilic metal chelator DP-109 reduces amyloid pathology in brains of human betaamyloid precursor protein transgenic mice. Neurobiol Aging 25:1315-1321.

Levine III H (1995) Soluble multimeric Alzheimer beta(1-40) pre-amyloid complexes in dilute solution. Neurobiol Aging 16:755-764.

Li LB, Toan SV, Zelenaia O, Watson DJ, Wolfe JH, Rothstein JD, Robinson MB (2006) Regulation of astrocytic glutamate transporter expression by Akt: evidence for a selective transcriptional effect on the GLT-1/EAAT2 subtype. J Neurochem 97:759-771.

Liang Z, Valla J, Sefidvash-Hockley S, Rogers J, Li R (2002) Effects of estrogen treatment on glutamate uptake in cultured human astrocytes derived from cortex of Alzheimer's disease patients. J Neurochem 80:807-814.

Lim GP, Calon F, Morihara T, Yang F, Teter B, Ubeda O, Salem Jr N, Frautschy SA, Cole GM (2005) A diet enriched with the omega-3 fatty acid docosahexaenoic acid reduces amyloid burden in an aged Alzheimer mouse model. J Neurosci 25:3032-3040.

Liu SF, Ye X, Malik AB (1999) Inhibition of NF-kappaB activation by pyrrolidine dithiocarbamate prevents In vivo expression of proinflammatory genes. Circulation 100:1330-1337.

London JA, Biegel D, Pachter JS (1996) Neurocytopathic effects of betaamyloid-stimulated monocytes: a potential mechanism for central nervous system damage in Alzheimer disease. Proc Natl Acad Sci USA 93:4147-4152.

Lovell MA, Robertson JD, Teesdale WJ, Campbell JL, Markesbery WR (1998) Copper, iron and zinc in Alzheimer's disease senile plaques. J Neurol Sci 158:47-52.

Ma QL, Lim GP, Harris-White ME, Yang F, Ambegaokar SS, Ubeda OJ, Glabe CG, Teter B, Frautschy SA, Cole GM (2006) Antibodies against betaamyloid reduce Abeta oligomers, glycogen synthase kinase-3beta activation and tau phosphorylation in vivo and in vitro. J Neurosci Res 83:374-384.

Magrane J, Rosen KM, Smith RC, Walsh K, Gouras GK, Querfurth HW (2005) Intraneuronal $\beta$-amyloid expression downregulates the Akt survival pathway and blunts the stress response. J Neurosci 25:10960-10969.

Mandelkow EM, Drewes G, Biernat J, Gustke N, Van Lint J, Vandenheede JR, Mandelkow E (1992) Glycogen synthase kinase-3 and the Alzheimerlike state of microtubule-associated protein tau. FEBS Lett 314:315-321.

Masliah E, Alford M, DeTeresa R, Mallory M, Hansen L (1996) Deficient glutamate transport is associated with neurodegeneration in Alzheimer's disease. Ann Neurol 40:759-766.

Masliah E, Alford M, Mallory M, Rockenstein E, Moechars D, Van Leuven F (2000) Abnormal glutamate transport function in mutant amyloid precursor protein transgenic mice. Exp Neurol 163:381-387. 
Maynard CJ, Cappai R, Volitakis I, Cherny RA, White AR, Beyreuther K, Masters CL, Bush AI, Li QX (2002) Overexpression of Alzheimer's disease amyloid-beta opposes the age-dependent elevations of brain copper and iron. J Biol Chem 277:44670-44676.

Meda L, Cassatella MA, Szendrei GI, Otvos Jr L, Baron P, Villalba M, Ferrari D, Rossi F (1995) Activation of microglial cells by beta-amyloid protein and interferon-gamma. Nature 374:647-650.

Miura T, Mitani S, Takanashi C, Mochizuki N (2004) Copper selectively triggers beta-sheet assembly of an N-terminally truncated amyloid betapeptide beginning with Glu3. J Inorg Biochem 98:10-14.

Nakagawa Y, Nakamura M, McIntosh TK, Rodriguez A, Berlin JA, Smith DH, Saatman KE, Raghupathi R, Clemens J, Saido TC, Schmidt ML, Lee VM, Trojanowski JQ (1999) Traumatic brain injury in young, amyloid-beta peptide overexpressing transgenic mice induces marked ipsilateral hippocampal atrophy and diminished Abeta deposition during aging. J Comp Neurol 411:390-398.

Nakagawa Y, Reed L, Nakamura M, McIntosh TK, Smith DH, Saatman KE, Raghupathi R, Clemens J, Saido TC, Lee VM, Trojanowski JQ (2000) Brain trauma in aged transgenic mice induces regression of established abeta deposits. Exp Neurol 163:244-252.

Noshita N, Sugawara T, Lewen A, Hayashi T, Chan PH (2003) Copper-zinc superoxide dismutase affects Akt activation after transient focal cerebral ischemia in mice. Stroke 34:1513-1518.

Nurmi A (2004) The role of nuclear factor kappa-B in models of adult and neonatal cerebral ischemia. The effects of pyrrolidine dithiocarbamate. Doctoral dissertation, Kuopio University Publications.

Nurmi A, Vartiainen N, Pihlaja R, Goldsteins G, Yrjanheikki J, Koistinaho J (2004) Pyrrolidine dithiocarbamate inhibits translocation of nuclear factor kappa-B in neurons and protects against brain ischaemia with a wide therapeutic time window. J Neurochem 91:755-765.

Nurmi A, Goldsteins G, Narvainen J, Pihlaja R, Ahtoniemi T, Grohn O, Koistinaho J (2006) Antioxidant pyrrolidine dithiocarbamate activates Akt-GSK signaling and is neuroprotective in neonatal hypoxia-ischemia. Free Radic Biol Med 40:1776-1784.

Opazo C, Huang X, Cherny RA, Moir RD, Roher AE, White AR, Cappai R, Masters CL, Tanzi RE, Inestrosa NC, Bush AI (2002) Metalloenzymelike activity of Alzheimer's disease beta-amyloid. Cu-dependent catalytic conversion of dopamine, cholesterol, and biological reducing agents to neurotoxic $\mathrm{H}_{2} \mathrm{O}_{2}$. J Biol Chem 277:40302-40308.

Orwar O, Fishman HA, Ziv NE, Scheller RH, Zare RN (1995) Use of 2,3naphthalenedicarboxaldehyde derivatization for single-cell analysis of glutathione by capillary electrophoresis and histochemical localization by fluorescence microscopy. Anal Chem 67:4261-4268.

Ostrakhovitch EA, Lordnejad MR, Schliess F, Sies H, Klotz LO (2002) Copper ions strongly activate the phosphoinositide-3-kinase/Akt pathway independent of the generation of reactive oxygen species. Arch Biochem Biophys 397:232-239.

Pei JJ, Tanaka T, Tung YC, Braak E, Iqbal K, Grundke-Iqbal I (1997) Distribution, levels, and activity of glycogen synthase kinase- 3 in the Alzheimer disease brain. J Neuropathol Exp Neurol 56:70-78.

Pei JJ, Braak E, Braak H, Grundke-Iqbal I, Iqbal K, Winblad B, Cowburn RF (1999) Distribution of active glycogen synthase kinase 3beta (GSK3beta) in brains staged for Alzheimer disease neurofibrillary changes. J Neuropathol Exp Neurol 58:1010-1019.
Phinney AL, Drisaldi B, Schmidt SD, Lugowski S, Coronado V, Liang Y, Horne P, Yang J, Sekoulidis J, Coomaraswamy J, Chishti MA, Cox DW, Mathews PM, Nixon RA, Carlson GA, St George-Hyslop P, Westaway D (2003) In vivo reduction of amyloid-beta by a mutant copper transporter. Proc Natl Acad Sci USA 100:14193-14198.

Reisinger EC, Kern P, Ernst M, Bock P, Flad HD, Dietrich M (1990) Inhibition of HIV progression by dithiocarb. German DTC Study Group. Lancet 335:679-682.

Rockenstein E, Torrance M, Mante M, Adame A, Paulino A, Rose JB, Crews L, Moessler H, Masliah E (2006) Cerebrolysin decreases amyloid-beta production by regulating amyloid protein precursor maturation in a transgenic model of Alzheimer's disease. J Neurosci Res 83:1252-1261.

Sanna PP, Cammalleri M, Berton F, Simpson C, Lutjens R, Bloom FE, Francesconi W (2002) Phosphatidylinositol 3-kinase is required for the expression but not for the induction or the maintenance of long-term potentiation in the hippocampal CA1 region. J Neurosci 22:3359-3365.

Sastre M, Dewachter I, Rossner S, Bogdanovic N, Rosen E, Borghgraef P, Evert BO, Dumitrescu-Ozimek L, Thal DR, Landreth G, Walter J, Klockgether T, van Leuven F, Heneka MT (2006) Nonsteroidal antiinflammatory drugs repress beta-secretase gene promoter activity by the activation of PPARgamma. Proc Natl Acad Sci USA 103:443-448.

Schreck R, Meier B, Mannel DN, Droge W, Baeuerle PA (1992) Dithiocarbamates as potent inhibitors of nuclear factor kappa B activation in intact cells. J Exp Med 175:1181-1194.

Squitti R, Lupoi D, Pasqualetti P, Dal Forno G, Vernieri F, Chiovenda P, Rossi L, Cortesi M, Cassetta E, Rossini PM (2002) Elevation of serum copper levels in Alzheimer's disease. Neurology 59:1153-1161.

Takashima A, Noguchi K, Michel G, Mercken M, Hoshi M, Ishiguro K, Imahori K (1996) Exposure of rat hippocampal neurons to amyloid beta peptide (25-35) induces the inactivation of phosphatidyl inositol-3 kinase and the activation of tau protein kinase I/glycogen synthase kinase- 3 beta. Neurosci Lett 203:33-36.

Townsend KP, Pratico D (2005) Novel therapeutic opportunities for Alzheimer's disease: focus on nonsteroidal anti-inflammatory drugs. FASEB J 19:1592-1601.

Verhaegh GW, Richard MJ, Hainaut P (1997) Regulation of p53 by metal ions and by antioxidants: dithiocarbamate down-regulates p53 DNAbinding activity by increasing the intracellular level of copper. Mol Cell Biol 17:5699-5706.

Watson GS, Cholerton BA, Reger MA, Baker LD, Plymate SR, Asthana S, Fishel MA, Kulstad JJ, Green PS, Cook DG, Kahn SE, Keeling ML, Craft S (2005) Preserved cognition in patients with early Alzheimer disease and amnestic mild cognitive impairment during treatment with rosiglitazone: a preliminary study. Am J Geriatr Psychiatry 13:950-958.

Weihl CC, Ghadge GD, Kennedy SG, Hay N, Miller RJ, Roos RP (1999) Mutant presenilin-1 induces apoptosis and downregulates Akt/PKB. J Neurosci 19:5360-5369.

Wiltfang J, Smirnov A, Schnierstein B, Kelemen G, Matthies U, Klafki HW, Staufenbiel M, Huther G, Ruther E, Kornhuber J (1997) Improved electrophoretic separation and immunoblotting of beta-amyloid (A beta) peptides 1-40, 1-42, and 1-43. Electrophoresis 18:527-532.

Zou K, Gong JS, Yanagisawa K, Michikawa M (2002) A novel function of monomeric amyloid $\beta$-protein serving as an antioxidant molecule against metal-induced oxidative damage. J Neurosci 22:4833-4841. 